\title{
Recurrent selection for high iron and zinc concentrations in black bean grain
}

\author{
Lara Rodrigues de Queiroz ${ }^{1}$ (D), Ludivina Lima Rodrigues ${ }^{1}$ (D), Saulo Muniz Martins² (D), Thiago Lívio \\ Pessoa Oliveira de Souza² (D), Leonardo Cunha Melo² (D), Helton Santos Pereira ${ }^{2, \star}$ (D) \\ 1. Universidade Federal de Goiás - Escola de Agronomia - Melhoramento de Plantas - Goiânia (GO), Brazil. \\ 2. Embrapa Arroz e Feijão - Pesquisa - Melhoramento de Feijão - Santo Antônio de Goiás (GO), Brazil. \\ Received: Oct. 11, 2020 | Accepted: Feb. 19, 2021 \\ Section Editor: Freddy Mora \\ *Corresponding author: helton.pereira@embrapa.br \\ How to cite: Queiroz, L. R., Rodrigues, L. L., Martins, S. M., Souza, T. K. P. O., Melo, L. C. and Pereira, H. S. (2021). Recurrent selection for high \\ iron and zinc concentrations in black bean grain. Bragantia, 80, e3121. https://doi.org/10.1590/1678-4499.20200489
}

\begin{abstract}
The iron concentration ( $\mathrm{FeC}$ ) and zinc concentration $(\mathrm{ZnC})$ in common bean grain are quantitative traits, and appropriate breeding techniques are required to achieve genetic gain. The aim of this study was to obtain a recurrent selection population of black bean to increase the $\mathrm{FeC}$ and $\mathrm{ZnC}$ in the grain and to select the superior progenies for formation of the next cycle and obtain lines. The base population was formed by crosses among ten parents. A total of 351 progenies were obtained, and, after two generations of selection, the 27 best progenies were evaluated in two field trials for $\mathrm{FeC}, \mathrm{ZnC}, 100$ seed weight and yield. Analyses of variance were carried out and genetic parameters were estimated. The heritability estimates ranged from 59 to $94 \%$ for the four traits. The estimates of expected gain from direct selection for each trait (3 to $21 \%$ ) and simultaneous selection (1 to $4 \%$ ) indicate success from selection. The eight progenies, selected based on simultaneous selection, have superior mean values, including to those of 'BRS Supremo' ( $10 \%$ for FeC, $8 \%$ for ZnC, $5 \%$ for 100 seed weight and 3.8\% for yield), the Brazilian black bean cultivar with the highest FeC and $\mathrm{ZnC}$. The recurrent selection population shows high genetic variability and potential for obtaining lines superior to the cultivars currently on the market, allying high agronomic performance and high $\mathrm{FeC}$ and $\mathrm{ZnC}$ in the grain. Furthermore, this population shows potential for generating a new recurrent selection cycle, from recombination of the eight superior progenies.
\end{abstract}

Key words: Phaseolus vulgaris, biofortification, yield, 100 seed weight.

\section{INTRODUCTION}

Common bean or dry edible bean (Phaseolus vulgaris L.) is the legume of greatest direct consumption in the world. Its prominence is also established by its high nutritional value, constituting an excellent source of protein, iron and zinc (FAO 2020); it is considered a staple food in South America, Central America and East Africa. Brazil is one of the main consumers and producers of common bean, producing approximately 2.7 million tons annually on 1.7 million hectares, with mean yield of 1,553 kg.ha-1 (Embrapa 2020). The black commercial group is the second most consumed in Brazil, representing approximately $20 \%$ of the total common bean produced annually (540,000 tons), in 340,000 hectares (Pereira et al. 2012). Therefore, this type of grain has great economic and social importance.

Iron and zinc deficiency is recognized as a problem for health throughout the world, especially affecting needy families that do not have access to foods with high protein and nutrient content. Iron is essential in forming hemoglobin, and its deficiency causes anemia (Welch 2002), afflicting approximately 26\% of the world population (WHO 2020). Zinc is an essential nutrient with numerous structural, biochemical and regulatory functions in human physiology. After iron, it is the micromineral of most abundant distribution in the human body. At least $17 \%$ of the world population has inadequate ingestion of zinc (Wessells and Brown 2012). 
Biofortification is a technique in which agricultural crops are modified or improved to accumulate more nutrients in their edible parts (Pérez-Massot et al. 2013), and it constitutes one of the main strategies for diminishing undernutrition. Thus, through plant breeding, a product of superior nutritional quality is achieved that has low cost of production and is accessible to the population. Common bean is a crop with a high potential for biofortification, because it is one of the vegetables with the highest iron concentration in its edible part (Pereira et al. 2014).

In Brazil, people consume $50 \mathrm{~g}$ of beans daily (Wander 2007). An average adult needs $14 \mathrm{mg}$ of iron and $7 \mathrm{mg}$ of zinc per day (Institute of Medicine, 2001). Consumption of grains of the cultivar 'Pérola', the most planted in Brazil, provides $24 \%$ of iron and $27 \%$ of zinc daily demand. The supply can be expanded with the development of biofortified cultivars.

Genetic variability for these traits has been reported in various studies on this crop (Araújo et al. 2003; Beebe et al. 2000; Di Prado et al. 2019; Gouveia et al. 2014; Martins et al. 2016; Ribeiro et al. 2008; Silva et al. 2012), which indicates potential for increasing these concentrations. Regarding the interaction between genotypes and environments, some papers reported that there was a relevant genotype by environment interaction for these two minerals (Cichy et al. 2009; Martins et al. 2016), while other studies detected importance only for zinc concentration (ZnC) (Blair et al. 2011; Ribeiro et al. 2008) or iron concentration (FeC) (Araújo et al. 2003).

In addition to nutritional quality, agronomic traits such as yield, grain weight, disease resistance and others must be considered in the breeding steps because they are essential for acceptance of new cultivars by producers and consumers (Menezes Júnior et al. 2008). In plant breeding programs, most agronomic traits have quantitative inheritance, which means that they are controlled by various genes of lesser effects and are highly affected by environments (Ramalho et al. 2012). In common bean, inheritance of $\mathrm{FeC}$ and $\mathrm{ZnC}$ has also been described as polygenic (Blair et al. 2009, 2010; Cichy et al. 2009; Izquierdo et al. 2018).

Thus, breeding methods that take the complex nature of these traits into account are required for continuous genetic gain. The recurrent selection method was initially proposed for allogamous plants; however, it has been successfully used in autogamous plants, especially in common bean for various traits, such as yield, reaction to angular leaf spot, plant architecture and early maturity (Alves et al. 2015; Arantes et al. 2010; Menezes Júnior et al. 2008, 2013; Pires et al. 2014; Silva et al. 2007). Nevertheless, for nutritional traits, such as $\mathrm{FeC}$ and $\mathrm{ZnC}$, there are no studies using recurrent selection in common bean.

Furthermore, information on genetic parameters is essential for evaluating genetic progress in each selection cycle, as well as the genetic variability obtained, and, thus, for designing efficient strategies for development of cultivars with higher nutritional value. Therefore, the aim of this study was to obtain a recurrent selection population for increasing the $\mathrm{FeC}$ and $\mathrm{ZnC}$ in common bean grain, check the effectiveness of recurrent selection in generating progenies with higher concentrations of these minerals, and select the best progenies for recombination and formation of the next recurrent selection cycle and for obtaining lines.

\section{MATERIAL AND METHODS}

The base population was formed by crosses between ten parents that had high $\mathrm{FeC}$ and $\mathrm{ZnC}$ in the grain ('Xamego'/'Piratã 1'//'Iapar 5'/'G6495'///'BRS Grafite'/ 'G6492'/4/'BRS Supremo'/'Brasil 0001'//'Milionário'/‘BRS Esplendor'///Xamego'/'Piratã 1'); one parent was from the mulatinho commercial group ('Piratã 1'), one of brown color ('Brasil 0001'), and the others from the black commercial group (Pereira et al. 2014; 2018). The crosses and other steps of development of the progenies were performed in Santo Antônio de Goiás under protective screening in 2012 and 2013, up to formation of the base population.

In 2014, around 500 seeds obtained from the base population were sown, forming the $\mathrm{C}_{0} \mathrm{~S}_{0}$ generation in the winter crop season in the field in $244 \mathrm{~m}$ rows. At harvest, 351 plants were selected and harvested individually, forming the $\mathrm{C}_{0} \mathrm{~S}_{0: 1}$ generation. The $351 \mathrm{C}_{0} \mathrm{~S}_{0: 1}$ progenies were sown in the field in 2015, each one in a plot consisting of one $3 \mathrm{~m}$ row, inserting a check cultivar ('BRS Supremo') after every nine progenies. Of these progenies, 250 were discarded for not exhibiting the agronomic standard desired (i.e., the plants had very prostrate plant architecture and were susceptible to the main diseases) or for not having black grain at harvest. 
Seeds of the $101 \mathrm{C}_{0} \mathrm{~S}_{0: 1}$ progenies selected and of the check cultivars were sent for analysis of FeC and $\mathrm{ZnC}$. From the results obtained, 64 progenies with higher $\mathrm{FeC}$ and $\mathrm{ZnC}$ were selected. These 64 progenies were once more evaluated for $\mathrm{FeC}$ and $\mathrm{ZnC}$ in the 2016 winter crop season in the $\mathrm{C}_{0} \mathrm{~S}_{0: 2}$ generation. Considering the $\mathrm{FeC}$ and $\mathrm{ZnC}$ obtained in the two generations together, 27 progenies were selected with higher $\mathrm{FeC}$ and $\mathrm{ZnC}$, which, in the $\mathrm{C}_{0} \mathrm{~S}_{0: 3}$ generation, composed two experiments, including three check cultivars: 'BRS Esteio, 'BRS Supremo' and 'Xamego'. The 'BRS Supremo' and 'Xamego' cultivars have higher $\mathrm{FeC}$ and $\mathrm{ZnC}$ in the grain compared to the cultivars currently available on the market (Pereira et al. 2014); 'BRS Esteio' (Pereira et al. 2013) is currently the black bean cultivar most grown in Brazil, with excellent agronomic performance and commercial grain quality.

The trials were conducted in 2017 in Brasília (DF) and Santo Antônio de Goiás (GO) in the winter crop season (sowing in May/June and harvest from August to October). The experimental design used was randomized blocks with three replications, and plots were constituted by three $3 \mathrm{~m}$ rows and between-row spacing of $0.5 \mathrm{~m}$. The grain from the plots was weighed for yield determination, given in $\mathrm{g} \cdot \mathrm{plot}^{-1}$ and transformed into $\mathrm{kg} \cdot \mathrm{ha}^{-1}$. From each plot, 100 bean grains were removed at random for determination of 100 seed weight in $\mathrm{g} \cdot 100$ seeds $^{-1}$. After that, these seeds were used for determination of the $\mathrm{FeC}$ and $\mathrm{ZnC}$ in the grain.

The $\mathrm{FeC}$ and $\mathrm{ZnC}$ analyses were carried out a single time by acid digestion of the organic matter (with a 2:1 nitricperchloric acid mixture) according to the flame atomic absorption spectrophotometry technique, adapted from the Association of Official Analytical Chemists (AOAC 1995). To check the accuracy of the analyses, for each 40 samples, one was performed in triplicate and two were laboratory control samples with known concentrations. The grain was rapidly washed with deionized water and subsequently dried in a laboratory oven at $60{ }^{\circ} \mathrm{C}$ for $12 \mathrm{~h}$ (to $6 \%$ moisture content). The grain was ground ( $\leq 200 \mathrm{mesh}$ ) in a zirconium oxide ball mill (Retsch MM200). The sample was predigested with an acid mixture $\left(50{ }^{\circ} \mathrm{C} / 30 \mathrm{~min}\right.$.), followed by digestion proper $\left(100^{\circ} \mathrm{C} / 30 \mathrm{~min} . ; 170^{\circ} \mathrm{C} / 3 \mathrm{~h}\right.$; cooling at ambient temperature, and new addition of $2 \mathrm{~mL}$ of acid mixture and digestion at $170^{\circ} \mathrm{C} / 3 \mathrm{~h}$ ). The extract obtained was adequately diluted and read in an atomic absorption spectrophotometer (AGILENT/VARIAN model SpectrAA 50 B) calibrated with a standard curve for iron and zinc.

The statistical analyses were processed with the aid of the Genes software (Cruz 2013). Individual analyses of variance were carried out for all the traits, and joint analyses involving the data from the two environments. The effects of genotypes and environments were considered fixed. The experimental coefficient of variation (CV[\%]) and selective accuracy (SA) (Resende and Duarte 2007) were estimated to evaluate the accuracy and the informativeness of the experiments.

Genetic and phenotypic parameters were estimated, such as genetic variance, heritability and gains expected from selection, with selection intensity of $30 \%$ of the best progenies. As the genotype effect was considered fixed, it should be noted that the heritability calculated refers to the genotypic coefficient of determination. The estimates of the confidence intervals of heritability were obtained through expressions developed by Knapp et al. (1985).

For simultaneous selection, the "weight-free" and "parameter-free" multiplicative index proposed by Elston (1963) was used, in which minimum or maximum values are pre-established. For $\mathrm{FeC}$ and $\mathrm{ZnC}$, the minimum value was the overall mean of the experiments; and for yield and 100 seed weight, the minimum values were those of the 'Xamego' check cultivar. Gain based on the combined traits was then calculated. The eight best progenies were selected for recombination.

\section{RESULTS AND DISCUSSION}

The mean values of the 101 progenies in the COS0:1 generation were $71.4 \mathrm{mg} \cdot \mathrm{kg}^{-1}$ for $\mathrm{FeC}$ and $39.4 \mathrm{mg} \cdot \mathrm{kg}^{-1}$ for $\mathrm{ZnC}$, which were lower than the mean values of the check cultivar 'BRS Supremo' ( $72.7 \mathrm{mg} \cdot \mathrm{kg}^{-1}$ for FeC and $40.6 \mathrm{mg} \cdot \mathrm{kg}^{-1}$ for ZnC) (Table 1). However, the mean values of the 64 selected progenies were superior to those of 'BRS Supremo' $\left(75.5 \mathrm{mg} \cdot \mathrm{kg}^{-1}\right.$ for $\mathrm{FeC}$, ranging from 56.5 to $93.9 \mathrm{mg} \cdot \mathrm{kg}^{-1}$ and $40.1 \mathrm{mg} \cdot \mathrm{kg}^{-1}$ for $\mathrm{ZnC}$, ranging from 30.2 to $51.4 \mathrm{mg} \cdot \mathrm{kg}^{-1}$ ). Some progenies that exhibited a very high concentration for one of the minerals and lower than that of the check cultivar for the other were also selected, which explains minimum values below the mean of the check cultivar. 
Table 1. Summary of the results of evaluation and selection of the progenies for iron concentrations $(\mathrm{FeC})$ and zinc concentrations ( $\mathrm{ZnC})$ in the grain in different generations.

\begin{tabular}{|c|c|c|c|c|}
\hline \multirow{2}{*}{ Trait } & \multirow{2}{*}{ Measurement } & \multicolumn{3}{|c|}{ Generation } \\
\hline & & $C_{0} S_{0: 1}$ & $\mathrm{C}_{0} \mathrm{~S}_{0: 2}$ & $\mathbf{C}_{0} \mathrm{~S}_{0: 3}$ \\
\hline & No. of progenies & 101 & 64 & 27 \\
\hline & Selection intensity & $63 \%$ & $42 \%$ & $30 \%$ \\
\hline \multirow{4}{*}{$\mathrm{FeC}$} & Mean of the Progenies & 71.4 & 78.8 & 68.4 \\
\hline & Variance & 53.2 & 139.2 & 14.3 \\
\hline & Mean of BRS Supremo & 72.7 & 77.4 & 64.3 \\
\hline & Mean of those selected & 75.5 & 87.8 & 71.6 \\
\hline \multirow{4}{*}{$\mathrm{ZnC}$} & Mean of the Progenies & 39.4 & 42.8 & 44.3 \\
\hline & Variance & 8.0 & 18.4 & 4.1 \\
\hline & Mean of BRS Supremo & 40.6 & 40.7 & 42.1 \\
\hline & Mean of those selected & 40.1 & 44.8 & 45.8 \\
\hline
\end{tabular}

In evaluation of the $\mathrm{C}_{0} \mathrm{~S}_{0: 2}$ generation, as expected, the mean values of the 64 progenies $\left(78.8 \mathrm{mg} \cdot \mathrm{kg}^{-1}\right.$ for $\mathrm{FeC}$ and $42.8 \mathrm{mg} \cdot \mathrm{kg}^{-1}$ for $\mathrm{ZnC}$ ) were higher than those of 'BRS Supremo' (77.4 mg.kg-1 for FeC and $40.7 \mathrm{mg} \cdot \mathrm{kg}^{-1}$ for $\mathrm{ZnC}$ ) (Table 1). In the mean of the two evaluations, the 64 progenies had mean values of $\mathrm{FeC}\left(75.2 \mathrm{mg} \cdot \mathrm{kg}^{-1}\right)$ and of $\mathrm{ZnC}$ (41.1 mg. $\mathrm{kg}^{-1}$ ) higher than those of 'BRS Supremo' (74.6 and $40.5 \mathrm{mg} \cdot \mathrm{kg}^{-1}$, respectively) (Table 1), which indicates the possibility of obtaining lines with concentrations higher than those of that cultivar. As already mentioned, 'BRS Supremo' is currently the black bean cultivar with the highest concentrations of these minerals (Pereira et al. 2018).

This is important because the final aim of any recurrent selection program in the case of autogamous plants should be to obtain lines superior to the existing cultivars for the trait in question, for use as new cultivars. From these results, 27 progenies with $\mathrm{FeC}$ ranging from 75.4 to $91.4 \mathrm{mg} \cdot \mathrm{kg}^{-1}$ and $\mathrm{ZnC}$ ranging from 37.3 to $45.6 \mathrm{mg} \cdot \mathrm{kg}^{-1}$ were selected for evaluation in experiments with replications in different environments. These progenies exhibited even higher mean values (81.6 $\mathrm{mg} \cdot \mathrm{kg}^{-1}$ for $\mathrm{FeC}$ and $42.4 \mathrm{mg} \cdot \mathrm{kg}^{-1}$ for $\mathrm{ZnC}$ ).

Considering evaluation of the progenies in the experiments, the estimates of the coefficient of variation (CV) ranged from 6.4 to $10.9 \%$ for $\mathrm{FeC}$ and from 5.1 to $7.4 \%$ for $\mathrm{ZnC}$, indicating good experimental accuracy (Table 2). The estimates of selective accuracy (SA) for these traits were considered to be of moderate to high magnitude, ranging from 0.61 to 0.73 for $\mathrm{FeC}$ and from 0.74 to 0.75 for $\mathrm{ZnC}$, confirming the good discrimination capacity of the treatments. These results were similar to those obtained by Di Prado et al. (2019), Martins et al. (2016), Pereira et al. (2014) and Silva et al. (2012).

Table 2. Summary of the individual analyses of variance for iron and zinc concentrations ( $\left.\mathrm{mg} \cdot \mathrm{kg}^{-1}\right), 100$ seed weight (grams), and grain yield $\left(\mathrm{kg} \cdot \mathrm{ha}^{-1}\right)$ of the check cultivars and of the 27 progenies evaluated in Santo Antônio de Goiás (STA) and Brasília (BSB), winter/2017.

\begin{tabular}{|c|c|c|c|c|c|c|c|c|}
\hline \multirow{3}{*}{$\begin{array}{l}\text { Source of } \\
\text { variation }\end{array}$} & \multirow{3}{*}{ DF } & \multicolumn{2}{|c|}{ Iron concentration } & \multicolumn{2}{|c|}{ Zinc concentration } & \multicolumn{2}{|c|}{100 seed weight } & \multirow{2}{*}{$\begin{array}{c}\text { Grain yield } \\
\text { BSB }\end{array}$} \\
\hline & & STA & BSB & STA & BSB & STA & BSB & \\
\hline & & MS & MS & MS & MS & MS & MS & MS \\
\hline Blocks & 2 & 41.4 & 22.3 & 42.2 & 21.9 & 1.4 & 6.70 & 16862 \\
\hline Genotypes & 29 & $46.3^{* *}$ & $78.7^{\text {ns }}$ & $11.0^{\star *}$ & $25.8^{* *}$ & $11.3^{\star *}$ & $7.61^{* *}$ & $158543^{\star *}$ \\
\hline Progenies $(\mathrm{P})$ & 26 & $43.0^{*}$ & $86.0^{*}$ & $10.0^{* *}$ & $28.3^{* *}$ & $10.9^{* *}$ & $7.84^{* *}$ & $168230^{\star *}$ \\
\hline Check (C) & 2 & $69.3^{*}$ & $18.2^{\text {ns }}$ & $4.9^{\text {ns }}$ & $6.0^{\text {ns }}$ & $18.4^{\star *}$ & $2.21^{\mathrm{ns}}$ & $105631^{\text {ns }}$ \\
\hline Pvs. C & 1 & $84.5^{\text {ns }}$ & $7.2^{\mathrm{ns}}$ & $49.6^{* *}$ & $0.9^{\text {ns }}$ & $8.6^{* *}$ & $12.47^{* *}$ & $12516^{\mathrm{ns}}$ \\
\hline Residue & 58 & 21.5 & 48.7 & 4.7 & 11.6 & 0.3 & 1.58 & 38927 \\
\hline Mean & & 72.6 & 64.1 & 42.5 & 45.8 & 23.7 & 20.2 & 964 \\
\hline $\mathrm{CV}(\%)^{1}$ & & 6.4 & 10.9 & 5.1 & 7.4 & 2.2 & 6.2 & 19.9 \\
\hline $\mathrm{SA}^{2}$ & & 0.73 & 0.61 & 0.75 & 0.74 & 0.98 & 0.89 & 0.88 \\
\hline
\end{tabular}

${ }^{1}$ Experimental coefficient of variation; ${ }^{2}$ Selective accuracy. $n s,{ }^{*},{ }^{* *}$ not significant, significant at $p<0.05$ and significant at $p<0.01$, respectively. 
For grain yield, the CV was 19.9\% (Table 2) considering only the trial in Brasília, given that, in the trial in Santo Antônio de Goiás, the estimates of the experimental quality parameters were not satisfactory $(\mathrm{CV}=34 \%)$. The estimate of SA was 0.88 , which is considered high for grain yield. For 100 seed weight, the CV ranged from 2.2 to $6.2 \%$, and the SA ranged from 0.89 to 0.98 , considered very high. These estimates indicated good experimental precision for the two traits and they are similar to those reported by Chiorato et al. (2015) and Santos et al. (2018).

Considering the individual analyses of variance (Table 2) and joint analyses of variance (Table 3), there was a significant difference for the four traits, indicating genetic variability among the progenies. Even after a previous step of selection, which led to the group of 27 progenies, this result shows that there is still the possibility of selection of progenies with greater concentrations of these minerals for recombination and formation of a new recurrent selection cycle.

Table 3. Summary of the joint analyses of variance for iron and zinc concentrations in the grain $\left(\mathrm{mg}^{\mathrm{kg}} \mathrm{kg}^{-1}\right.$ ) and 100 seed weight (grams) of the check varieties and of the 27 progenies, evaluated in Santo Antônio de Goiás and Brasília in winter/2017.

\begin{tabular}{|c|c|c|c|c|c|c|c|}
\hline \multirow{2}{*}{ Source of variation } & \multirow{2}{*}{ DF } & \multicolumn{2}{|c|}{ Iron concentration } & \multicolumn{2}{|c|}{ Zinc concentration } & \multicolumn{2}{|c|}{100 seed weight } \\
\hline & & MS & $P$ value & MS & $P$ value & MS & $P$ value \\
\hline Genotypes (G) & 29 & 80.8 & 0.001 & 23.2 & 0.001 & 15.4 & 0.001 \\
\hline Progenies $(P)$ & 26 & 85.2 & 0.001 & 24.4 & 0.001 & 15.2 & 0.001 \\
\hline Check cultivars (C) & 2 & 54.0 & 0.220 & 10.8 & 0.270 & 16.1 & 0.001 \\
\hline Pvs. C & 1 & 21.2 & 1.000 & 18.5 & 0.130 & 20.8 & 0.001 \\
\hline Environments (E) & 1 & 3255.5 & 0.001 & 484.6 & 0.020 & 536.5 & 0.001 \\
\hline $\mathrm{G} \times \mathrm{E}$ & 29 & 44.1 & 0.200 & 13.6 & 0.030 & 3.5 & 0.001 \\
\hline$P \times E$ & 26 & 43.9 & 0.210 & 13.9 & 0.030 & 3.6 & 0.001 \\
\hline $\mathrm{C} \times \mathrm{E}$ & 2 & 33.6 & 1.000 & 0.1 & 1.000 & 4.5 & 0.010 \\
\hline$(P$ vs $C) \times E$ & 1 & 70.5 & 0.161 & 32.0 & 0.050 & 0.2 & 1.000 \\
\hline Residue & 116 & 35.1 & - & 8.2 & - & 0.9 & \\
\hline Overall mean & & & 68.3 & & 44.2 & & 22.0 \\
\hline CV (\%)1 & & & 8.7 & & 6.5 & & 4.4 \\
\hline
\end{tabular}

${ }^{1}$ Experimental coefficient of variation.

There was also a significant effect of the environments, which highlights the heterogeneity between the two locations for the three traits (Table 3). The overall mean values of the progenies in the environments ranged from 64.1 to $72.6 \mathrm{mg} \cdot \mathrm{kg}^{-1}$ for $\mathrm{FeC}$, from 42.5 to $45.8 \mathrm{mg} \cdot \mathrm{kg}^{-1}$ for $\mathrm{ZnC}$, and from 20.2 to $23.7 \mathrm{~g}$ for 100 seed weight, confirming the direct effect of environments on the traits evaluated (Table 2). This indicates the importance of knowing which environmental factors and how environmental factors affect expression of $\mathrm{FeC}$ and $\mathrm{ZnC}$ in the grain, so that cultivars can be recommended in a reliable manner.

Environmental factors, such as type of soil, $\mathrm{pH}$, organic matter content and soil moisture, can affect both the uptake and the accumulation of these micronutrients in the grain (Ribeiro 2010). In geographic terms, there is a considerable difference in altitude between Santo Antônio de Goiás at $823 \mathrm{~m}$ and Brasília at 1,171 m, which leads to a considerable difference of temperature in the period in which the experiments were carried out (May to August). This is a preponderant factor in development of the common bean crop and can help explain the environmental effect detected.

In addition to the environmental effect, the genotype by environment interaction was observed for $\mathrm{ZnC}$ and 100 seed weight, which refers to the differential response of the genotypes between the environments. For $\mathrm{ZnC}$, similar results have been reported in the literature (Blair et al. 2010; Ribeiro et al. 2008). For 100 seed weight, this interaction does not always appear (Di Prado et al. 2019). For FeC, interaction was not detected, which diverges from what is normally reported in the literature (Araújo et al. 2003; Martins et al. 2016). This is considered a good result, since the ordering of the progenies is similar in the environments without distortions in the genotype responses. However, the fact of having been evaluated in only two environments in one crop season alone may explain the lack of the interaction effect. 
For all the traits, the estimates of genetic variance among the progenies, both in individual analyses and in joint analyses, confirmed the existence of genetic variability (Table 4). All the estimates of the confidence interval for heritability, except for $\mathrm{FeC}$ evaluated in Brasilia, exhibited lower limits greater than zero, indicating that there is still the possibility of success from selection. The heritability estimates based on joint analyses were 59\% (43 to 50\% in the environments) for FeC and $67 \%$ (52 to 59\% in the environments) for $\mathrm{ZnC}$, considered as moderate to high, which indicates a good possibility of success from selection, considering the quantitative nature of these traits.

Table 4. Estimates of genetic parameters in relation to the iron and zinc concentrations ( $\left.\mathrm{mg} \mathrm{kg}^{-1}\right), 100$ seed weight (grams) and grain yield $\left(\mathrm{kg} \cdot \mathrm{ha}^{-1}\right)$, evaluated in the 2017 winter crop season in Santo Antônio de Goiás (STA) and Brasília (BSB).

\begin{tabular}{|c|c|c|c|c|c|c|c|c|c|c|}
\hline \multirow{2}{*}{ Parameter } & \multicolumn{3}{|c|}{ Iron concentration } & \multicolumn{3}{|c|}{ Zinc concentration } & \multicolumn{3}{|c|}{100 seed weight } & \multirow{2}{*}{$\begin{array}{c}\text { Grain } \\
\text { yield } \\
\text { BSB }\end{array}$} \\
\hline & STA & BSB & JOIN & STA & BSB & JOINT & STA & BSB & JOINT & \\
\hline Overall mean & 72.6 & 64.1 & 68.3 & 42.5 & 46.0 & 44.2 & 23.7 & 20.2 & 22.0 & 964 \\
\hline $\begin{array}{l}\text { Mean of selected } \\
\text { progenies }\end{array}$ & 75.6 & 67.6 & 71.6 & 43.8 & 47.8 & 45.8 & 23.9 & 20.7 & 22.3 & 1012 \\
\hline$\sigma^{2} g^{1}$ & 7.2 & 12.4 & 8.3 & 1.7 & 5.6 & 2.7 & 3.5 & 2.1 & 2.4 & 43791 \\
\hline$h^{2}(\%)^{2}$ & 50.0 & 43.3 & 58.7 & 52.4 & 59.2 & 66.6 & 97.5 & 80.0 & 94.0 & 76.8 \\
\hline $\mathrm{Clh}^{2}(\%)^{3}$ & $10-51$ & $3-44$ & $26-59$ & $13-53$ & $25-60$ & $40-66$ & $95-98$ & $63-80$ & $89-94$ & $58-77$ \\
\hline GS $(30 \%)^{4}$ & 2.7 & 4.2 & 3.5 & 2.7 & 4.4 & 3.0 & 8.3 & 7.9 & 7.4 & 21.4 \\
\hline GSS $(30 \%)^{5}$ & - & - & 2.7 & - & - & 2.3 & - & - & 1.0 & 3.8 \\
\hline
\end{tabular}

${ }^{1}$ Genetic variance; ${ }^{2}$ heritability; ${ }^{3}$ confidence interval of heritability; ${ }^{4}$ expected gain from selection; ${ }^{5}$ expected gain from simultaneous selection.

Some authors obtained heritability estimates for $\mathrm{FeC}$ below those found in the present study (Jost et al. 2009); others obtained superior estimate (83.8\%) (Martins et al. 2016). This can be explained by the fact that heritability consists of an estimate intrinsic to the population under study, and that its magnitude depends on the genetic variability of the genotypes, number of environments and number of replications under evaluation. In relation to heritability for $\mathrm{ZnC}$, other studies have detected estimates (from 53 to 70\%) similar to those obtained in the present study (Martins et al. 2016; Rosa et al. 2010; Zemolin et al. 2016) (Table 4).

The heritability estimates for 100 seed weight were of high magnitude: $94 \%$ (80 to 97\%) (Table 4), as reported in other studies (Alvares et al. 2016; Di Prado et al. 2019; Melo et al. 2004), indicating high possibility of success from selection. For grain yield, heritability was $73 \%$, which was considered above average, since this trait normally has lower heritability (Ramalho et al. 2012). In general, the heritability estimates reinforce the potential of this population for selection of the four traits.

The expected gain from direct selection (GS) of the eight best progenies for each trait in isolation was 3.5\% for FeC, $3.0 \%$ for $\mathrm{ZnC}, 7.4 \%$ for 100 seed weight and $21.4 \%$ for grain yield (Table 4 ), from which it can be inferred that there is still the possibility of selection of progenies with higher concentrations of these minerals and with favorable agronomic phenotypes. The mean values of the eight best progenies for $\mathrm{FeC}\left(71.6 \mathrm{mg} \cdot \mathrm{kg}^{-1}\right)$ and for $\mathrm{ZnC}\left(45.8 \mathrm{mg} \cdot \mathrm{kg}^{-1}\right)$ were higher than the mean values of the 'Xamego' cultivar, the check cultivar that had the highest concentrations of these minerals (70.3 mg. $\mathrm{kg}^{-1}$ for $\mathrm{FeC}$ and $44.7 \mathrm{mg} \cdot \mathrm{kg}^{-1}$ for $\mathrm{ZnC}$ ), and also higher than those of 'BRS Supremo' (Table 5). The 'Xamego' cultivar, though it has high $\mathrm{FeC}$ and $\mathrm{ZnC}$, not only in this study but in others (Pereira et al. 2014), is no longer used commercially. The mean value of the progenies selected was $4.6 \%$ greater than the overall mean $\left(68.4 \mathrm{mg} \cdot \mathrm{kg}^{-1}\right)$ for $\mathrm{FeC}$ and $3.3 \%$ greater (44.2 $\left.\mathrm{mg} \cdot \mathrm{kg}^{-1}\right)$ for $\mathrm{ZnC}$.

The eight best progenies not only had nutritionally superior grain, but they also stood out for their agronomic traits, with mean grain yield (1,012 kg.ha-1) and 100 seed weight $(22.32 \mathrm{~g})$ higher than the mean of the 'Xamego' cultivar (750 kg.ha-1 and $19.19 \mathrm{~g}$ ) (Table 5). Considering all 27 progenies, $85 \%$ of them were better than the 'BRS Supremo' check cultivar for $\mathrm{FeC}, 89 \%$ for $\mathrm{ZnC}, 67 \%$ for yield and $74 \%$ for 100 seed weight. This indicates the high frequency of favorable alleles in this recurrent selection population and confirms the possibility of obtaining superior lines in the future. 
Table 5. Mean values of the 27 progenies and three check cultivars, overall mean, mean values of the best $30 \%$ of the progenies, and mean value of the progenies selected simultaneously for all the traits studied: iron concentration (FeC), zinc concentration ( $\mathrm{ZnC}$ ) ( $\left.\mathrm{mg} \cdot \mathrm{kg}^{-1}\right)$, 100 seed weight (100SW) (grams) and grain yield $\left(\mathrm{kg} \cdot \mathrm{ha}^{-1}\right)$.

\begin{tabular}{|c|c|c|c|c|}
\hline Progeny & $\mathrm{FeC}$ & $\mathrm{ZnC}$ & 100 SW & Grain yield \\
\hline $216206943^{*}$ & 70.2 & 45.2 & 21.1 & 980 \\
\hline $216206961^{\star}$ & 70.0 & 45.1 & 24.2 & 866 \\
\hline $216206962^{*}$ & 70.4 & 45.8 & 24.2 & 1192 \\
\hline 216206977 & 71.3 & 43.0 & 19.8 & 923 \\
\hline 216206978 & 65.9 & 40.0 & 23.2 & 1096 \\
\hline $216206987^{\star}$ & 68.3 & 47.2 & 20.9 & 920 \\
\hline 216206993 & 59.2 & 38.9 & 21.7 & 1706 \\
\hline $216207006^{\star}$ & 72.7 & 46.4 & 20.9 & 1042 \\
\hline 216207007 & 67.8 & 43.2 & 22.7 & 1125 \\
\hline 216207008 & 69.9 & 46.1 & 22.1 & 595 \\
\hline $216207009^{*}$ & 74.3 & 44.6 & 21.2 & 829 \\
\hline 216207012 & 68.2 & 44.5 & 22.5 & 1075 \\
\hline 216207013 & 61.2 & 41.4 & 22.1 & 641 \\
\hline 216207015 & 72.6 & 46.9 & 19.3 & 687 \\
\hline 216207017 & 68.1 & 45.0 & 21.6 & 858 \\
\hline 216207018 & 65.9 & 42.6 & 23.0 & 1085 \\
\hline 216207019 & 67.7 & 44.8 & 20.3 & 930 \\
\hline 216207023 & 64.3 & 42.2 & 21.9 & 1384 \\
\hline 216207025 & 72.3 & 44.1 & 22.1 & 950 \\
\hline 216207026 & 66.6 & 45.6 & 22.4 & 628 \\
\hline 216207027 & 70.4 & 43.3 & 27.4 & 879 \\
\hline $216207029^{\star}$ & 73.3 & 46.4 & 22.5 & 1137 \\
\hline $216207034^{*}$ & 73.5 & 45.8 & 23.5 & 1129 \\
\hline 216207037 & 63.2 & 45.4 & 21.0 & 795 \\
\hline 216207041 & 66.9 & 44.1 & 22.0 & 863 \\
\hline 216207042 & 65.2 & 45.4 & 21.9 & 875 \\
\hline 216206944 & 68.2 & 43.7 & 20.6 & 835 \\
\hline 'XAMEGO' & 70.3 & 44.7 & 19.2 & 750 \\
\hline 'BRS ESTEIO’ & 67.2 & 42.9 & 22.4 & 1123 \\
\hline 'BRS SUPREMO’ & 64.3 & 42.1 & 21.2 & 901 \\
\hline Overall mean & 68.3 & 44.2 & 22.0 & 960 \\
\hline Mean of the progenies & 68.4 & 44.3 & 22.1 & 964 \\
\hline Mean of the 8 progenies selected & 71.6 & 45.8 & 22.3 & 1012 \\
\hline
\end{tabular}

Progenies selected to be recombined to form cycle 1.

For a cultivar to be adopted by both farmers and consumers, high concentrations of $\mathrm{FeC}$ and $\mathrm{ZnC}$ must be accompanied by other satisfactory agronomic and commercial requirements. For that reason, it is important to perform simultaneous selection based on the four traits to identify the eight best progenies to be recombined, aiming to form a new generation of the recurrent selection program, as well as to obtain lines for the purpose of recommending new cultivars. Thus, the expected gain from simultaneous selection for all the traits was $2.7 \%$ for $\mathrm{FeC}, 2.3 \%$ for $\mathrm{ZnC}, 3.8 \%$ for yield and $1.0 \%$ for 100 seed weight (Table 4). This result reinforces that it is possible to select lines with high $\mathrm{FeC}$ and $\mathrm{ZnC}$, together with high yield and larger grain. 
Direct selection of these traits exhibits superior results (Table 5) compared to simultaneous selection. Nevertheless, the efficiency is lower because the traits are handled individually, making it difficult to obtain lines with the various traits of interest together; yet these would be the lines that have potential for becoming cultivars. The eight progenies selected were $10 \%$ superior for $\mathrm{FeC}, 8 \%$ for $\mathrm{ZnC}$, 5\% for seed weight, and 11\% for yield in relation to 'BRS Supremo', aggregating high grain nutritional quality ( $\mathrm{FeC}$ and $\mathrm{ZnC}$ ) and good agronomic quality.

Considering the estimates of genetic parameters obtained (high heritability and expressive gains from selection), the recurrent selection population formed shows wide variability and genetic potential for generation of lines with higher $\mathrm{FeC}$ and $\mathrm{ZnC}$ in the grain. The eight progenies chosen based on simultaneous selection were used for recombination and formation of a base population for a new recurrent selection cycle (C1S0 generation). An alternative that allows an increase in genetic variability in a recurrent selection population is adding parents outside of the recurrent selection program in the step of recombination for formation of a new cycle (Ramalho et al. 2012). In this respect, two lines of common bean with black seed coat from different origins were also included in the recombination, CNFP 18131 and CNFP 15701.

The CNFP 18131 line was developed at Embrapa Arroz e Feijão specifically for high $\mathrm{FeC}$ and $\mathrm{ZnC}$, from a population generated at CIAT (Colombia) (parents MIB154/SER14//SEN22/SER7). This line showed high FeC (80.9 mg. $\left.\mathrm{kg}^{-1}\right), \mathrm{ZnC}$ $\left(36.9 \mathrm{mg} \cdot \mathrm{kg}^{-1}\right)$, yield $\left(1,728 \mathrm{~kg} \cdot \mathrm{ha}^{-1}\right)$ and 100 seed weight $(24.9 \mathrm{~g})$ in the mean of nine evaluation environments. In relation to 'BRS Supremo', CNFP 18131 showed superiority of 8.5\% for FeC, 7.9\% for $\mathrm{ZnC}$, 8.5\% for yield and 28\% for 100 seed weight (personal communication, Helton Pereira, unpublished data).

The other line that was inserted in recombination is the elite line CNFP 15701. It was not developed specifically for higher $\mathrm{FeC}$ and $\mathrm{ZnC}$, but it was selected in the preliminary trials for black bean of Embrapa Arroz e Feijão in 2013 as an elite line that combined high $\mathrm{FeC}$ and $\mathrm{ZnC}\left(71.7\right.$ and $\left.37.3 \mathrm{mg} \cdot \mathrm{kg}^{-1}\right)$ and good yield $\left(2,117 \mathrm{~kg} \cdot \mathrm{ha}^{-1}\right)$ with excellent adaptability and good phenotypic stability. This line showed 7\% superiority for $\mathrm{FeC}$ and $10 \%$ for $\mathrm{ZnC}$ in relation to 'BRS Supremo', with yield similar to 'BRS Esplendor' (Martins et al. 2016).

In parallel, lines were obtained from these eight progenies selected, which will be evaluated for $\mathrm{FeC}, \mathrm{ZnC}$ and other traits of agronomic and commercial importance and, then, after some selection steps, they will be evaluated in multilocation trials to check for potential in becoming biofortified cultivars.

\section{CONCLUSION}

The recurrent selection population formed from the parents 'Brasil 0001', 'BRS Esplendor, 'BRS Grafite, 'BRS Supremo', 'G6492,' 'G6495', 'IAPAR 65,' 'Milionário, 'Piratã 1' and 'Xamego' shows high genetic variability and potential for obtaining lines superior to the cultivars currently on the market, allying high agronomic performance and high iron and zinc concentrations in the grain. Furthermore, this population shows potential for generating a new recurrent selection cycle, which already was obtained from recombination of the eight superior progenies and two external parents.

\section{AUTHORS' CONTRIBUTION}

Conceptualization: Pereira H. S.; Methodology: Pereira H. S., Melo L. C. and Souza, T. L. P. O.; Investigation: Pereira H. S., Melo L. C., Souza T. L. P. O., Queiroz L. R., Rodrigues L. L. and Martins S. M.; Writing - Original Draft: Pereira H. S., Queiroz L. R., Rodrigues L. L. and Martins S. M.; Writing - Review and Editing: Pereira H. S., Queiroz L. R., Rodrigues L. L. and Martins S. M.; Funding Acquisition: Pereira H. S., Melo L. C. and Souza, T. L. P. O.; Resources: Pereira H. S. and Melo L. C.; Supervision: Pereira H. S.

\section{DATA AVAILABILITY STATEMENT}

All dataset were generated or analyzed in the current study. 


\section{FUNDING}

Empresa Brasileira de Pesquisa Agropecuária

[https://doi.org/10.13039/501100003046]

Grant No. 20.18.01.009.00.03.001

Empresa Brasileira de Pesquisa Agropecuária/Harvest Plus

[https://doi.org/10.13039/501100003046]

Grant No. 20.19.00.118.00.04.001

Conselho Nacional de Pesquisa e Desenvolvimento Científico

[https://doi.org/10.13039/501100003593]

Grant No. 313274/2019-3

\section{ACKNOWLEDGMENTS}

Not applicable.

\section{REFERENCES}

[AOAC] Association of Official Analytical Chemists. (1995). Metals in plants and pet foods-atomic absorption spectrophotometric method. First action 1975. Final action 1988, AOAC-Official Methods of Analysis. Arlington: AOAC International.

[FAO] Food and Agriculture Organization. (2020). Faostat. [Accessed Mar. 24, 2020]. Available at: http://www.fao.org/faostat/en/\#data/ QC/visualize/

[WHO] World Health Organization. (2020). The World Health Report. Chapter 4. [Accessed Apr. 24, 2020]. https://www.who.int/whr/2002/ chapter4/en/index3.html

Alvares, R. C., Silva, F. C., Melo, L. C., Melo, P. G. S. and Pereira, H. S. (2016). Estimation of genetic parameters and selection of highyielding, upright common bean lines with slow seed-coat darkening. Genetics and Molecular Research, 15, gmr15049081. https://doi. org/10.4238/gmr15049081

Alves, A. F., Menezes Junior, J. Â. N., Menezes, V. M. P. S., Carneiro, J. E. S., Carneiro, P. C. S. and Alves, A. F. (2015). Genetic progress and potential of common bean families obtained by recurrent selection. Crop Breeding and Applied Biotechnology, 15, 218-226. https:// doi.org/10.1590/1984-70332015v15n4a38

Arantes, L. O., Abreu, Â. F. B. and Ramalho, M. A. P. (2010). Eight cycles of recurrent selection for resistance to angular leaf spot in common bean. Crop Breeding and Applied Biotechnology, 10, 232-237. https://doi.org/10.1590/S1984-70332010000300008

Araújo, R., Miglioranza, É., Montalvan, R., Destro, D., Gonçalves-Vidigal, M. C. and Moda-Cirino, V. (2003). Genotype x environment interaction effects on the iron content of common bean grains. Crop Breeding and Applied Biotechnology, 3, 269-274.

Beebe, S., Gonzalez, A. V. and Rengifo, J. (2000). Research on Trace Minerals in the Common Bean. Food and Nutrition Bulletin, 21, 387391. https://doi.org/10.1177/156482650002100408

Blair, M. W., Astudillo, C., Grusak, M. A., Graham, R. and Beebe, S. E. (2009). Inheritance of seed iron and zinc concentrations in common bean (Phaseolus vulgaris L.). Molecular Breeding, 23, 197-207. https://doi.org/10.1007/s11032-008-9225-z 
Blair, M. W., Medina, J. I., Astudillo, C., Rengifo, J., Beebe, S. E., Machado, G. and Grahan, R. (2010). QTL for seed iron and zinc concentration and content in a Mesoamerican common bean (Phaseolus vulgaris L.) population. Theoretical and Applied Genetics, 121, $1059-1070$. https://doi.org/10.1007/s00122-010-1371-0

Blair, M. W., Astudillo, C., Rengifo, J., Beebe, S. E. and Graham, R. (2011). QTL analyses for seed iron and zinc concentrations in an intragenepool population of Andean common beans (Phaseolus vulgaris L.). Theoretical and Applied Genetics, 122, 511-521. https://doi. org/10.1007/s00122-010-1465-8

Chiorato, A. F., Carbonell, S. A. M., Bosetti, F., Sasseron, G. R., Lopes, R. L. T. and Azevedo, C. V. G. (2015). Common bean genotypes for agronomic and market-related traits in VCU trials. Scientia Agricola, 72, 34-40. https://doi.org/10.1590/0103-9016-2013-0172

Cichy, K. A., Caldas, G. V., Snapp, S. S. and Blair, M. W. (2009). QTL Analysis of Seed Iron, Zinc, and Phosphorus Levels in an Andean Bean Population. Crop Science, 49, 1742-1750. https://doi.org/10.2135/cropsci2008.10.0605

Cruz, C. D. (2013). Programa Genes: Aplicativo computacional em Genética e Estatística Experimental. Viçosa: UFV. [Accessed Apr. 24, 2021]. Available at: http://www.ufv.br/dbg/genes/genes.htm

Di Prado, P. R. C., Faria, L. C., Souza, T. L. P. O., Melo, L. C., Melo, P. G. S. and Pereira, H. S. (2019). Genetic control and selection of common bean parents and superior segregant populations based on high iron and zinc contents, seed yield and 100- seed weight. Genetics and Molecular Research, 18, gmr18146. https://doi.org/10.4238/gmr18146

Elston, R. C. (1963). A weight-free index for the purpose of ranking or selection with respect to several traits at a time. Biometrics, 19, 85-97. https://doi.org/10.2307/2527573

[Embrapa] Empresa Brasileira de Pesquisa Agropecuária. (2019). Cyclical data on the production of common bean (Phaseolus vulgaris L.) and cowpea (Vigna unguiculata (L.) Walp) in Brazil-1985 to 2019. [Accessed Mar. 24, 2020]. Available at: http://www.cnpaf.embrapa. $\mathrm{br} /$ socioeconomia/index.htm

Gouveia, C. S. S., Freitas, G., Brito, J. H., Slaski, J. J. and Carvalho, M. Â. A. P. (2014). Nutritional and Mineral Variability in 52 Accessions of Common Bean Varieties (Phaseolus vulgaris L.) from Madeira Island. Agricultural Sciences, 5, 317-329. https://doi.org/10.4236/ as.2014.54034

Institute of Medicine. (2001). Dietary Reference intakes for vitamin A, vitamin K, arsenic, boron, chromium, copper, iodine, iron, manganese, molybdenum, nickel, silicon, vanadium, and zinc. Washington, DC: The National Academies Press. https://doi.org/10.17226/10026

Izquierdo, P., Astudillo, C., Blair, M. W., Iqbal, A. M., Raatz, B. and Cichy, K. A. (2018). Meta-QTL analysis of seed iron and zinc concentration and content in common bean (Phaseolus vulgaris L.). Theoretical and Applied Genetics, 131, 1645-1658. https://doi.org/10.1007/ s00122-018-3104-8

Jost, E., Ribeiro, N. D., Cerutti, T., Poersch, N. L. and Maziero, S. M. (2009). Potencial de aumento do teor de ferro em grãos de feijão por melhoramento genético. Bragantia, 68, 35-42. https://doi.org/10.1590/S0006-87052009000100005

Knapp, S. J., Stroup, W. W. and Ross, W. M. (1985). Exact Confidence Intervals for Heritability on a Progeny Mean Basis. Crop Science, 25, 192-194. https://doi.org/10.2135/cropsci1985.0011183X002500010046x

Martins, S. M., Melo, P. G. S., Faria, L. C., Souza, T. L. P. O., Melo, L. C. and Pereira, H. S. (2016). Genetic parameters and breeding strategies for high levels of iron and zinc in Phaseolus vulgaris L. Genetics and Molecular Research, 15, gmr.15028011. https://doi.org/10.4238/ gmr.15028011

Melo, L. C., Santos, J. B. and Ferreira, D. F. (2004). QTL mapping for common bean grain yield in different environments. Crop Breeding and Applied Biotechnology, 4, 135-144.

Menezes Júnior, J. Â. N., Ramalho, M. A. P. and Abreu, Â. F. B. (2008). Seleção recorrente para três caracteres do feijoeiro. Bragantia, 67, 833-838. https://doi.org/10.1590/S0006-87052008000400004 
Menezes Júnior, J. Â. N., Rezende Júnior, L. S., Rocha, G. S., Silva, V. M. P., Pereira, A. C., Carneiro, P. C. S., Peternelli, L. A. and Carneiro, J. E. S. (2013). Two cycles of recurrent selection in red bean breeding. Crop Breeding and Applied Biotechnology, 13, 41-48. https://doi. org/10.1590/S1984-70332013000100005

Pereira, H. S., Almeida, V. M., Melo, L. C., Faria, L. C., Wendland, A., Del Peloso, M. J. and Magaldi, M. C. S. (2012). Influência do ambiente em cultivares de feijoeiro-comum em cerrado com baixa altitude. Bragantia, 71, 165-172. https://doi.org/10.1590/S0006-87052012005000024

Pereira, H. S., Melo, L. C., Faria, L. C., Wendland, A., Del Peloso, M. J., Costa, J. G. C., Nascente, A. S., Díaz, J. L. C., Carvalho, H. W. L., Almeida, V. M., Melo, C. L. P., Costa, A. F., Posse, S. C. P., Magaldi, M. C. S., Abreu, A. F. B., Guimarães, C. M., Oliveira, J. P., Moreira, J. A. A. M., Martins, M. and Souza Filho, B. F. (2013). BRS Esteio - common bean cultivar with black grain, high yield potential and moderate resistance to anthracnose. Crop Breeding and Applied Biotechnology, 13, 373-376. https://doi.org/10.1590/S1984-70332013000400010

Pereira, H. S., Del Peloso, M. J., Bassinello, P. Z., Guimarães, C. M., Melo, L. C. and Faria, L. C. (2014). Genetic variability for iron and zinc content in common bean lines and interaction with water availability. Genetics and Molecular Research, 13, 6773-6785. https://doi. org/10.4238/2014.August.28.21

Pereira, H. S., Melo, L. C., Prado, P. R. C., Melo, P. G. S., Faria, L. C., Souza, T. L. P. O., Aguiar, M. S., Díaz, J. L. C., Almeida, V. M., Costa, A. F., Melo, C. L. P., Carvalho, H. W. L. and Pereira Filho, I. A. (2018) Cultivares de feijão com maiores teores de ferro, zinco e proteína nos grãos (Comunicado técnico 243). Santo Antônio de Goiás: Embrapa Arroz e Feijão. [Accessed Dec. 15, 2020]. Available at: https://ainfo. cnptia.embrapa.br/digital/bitstream/item/177474/1/CNPAF-2018-cot243.pdf

Pérez-Massot, E., Banakar, R., Gómez-Galera, S., Zorrilla-López, U., Sanahuja, G., Arjó, G., Miralpeix, B., Vamvaka, E., Farré, G., Rivera, S. M., Dashevskaya, S., Berman, J., Sabalza, M., Yuan, D., Bai, C., Bassie, L., Twyman, R. M., Capell, T., Christou, P. and Zhu, C. (2013). The contribution of transgenic plants to better health through improved nutrition: opportunities and constraints. Genes \& Nutrition, 8, $29-41$. https://doi.org/10.1007/s12263-012-0315-5

Pires, L. P. M., Ramalho, M. A. P., Abreu, Â. F. B. and Ferreira, M. C. (2014). Recurrent mass selection for upright plant architecture in common bean. Scientia Agricola, 71, 240-243. https://doi.org/10.1590/S0103-90162014000300009

Ramalho, M. A. P., Abreu, A. F. B., Santos, J. B. and Nunes, J. A. R. (2012). Aplicações da genética quantitativa no melhoramento de plantas autógamas. Lavras: UFLA.

Resende, M. D. V. and Duarte, J. B. (2007). Precisão e controle de qualidade em experimentos de avaliação de cultivares. Pesquisa Agropecuária Tropical, 37, 182-194.

Ribeiro, N. D., Jost, E., Cerutti, T., Mazieiro, S. M. and Poersch, N. L. (2008). Composição de microminerais em cultivares de feijão e aplicações para o melhoramento genético. Bragantia, 67, 267-273. https://doi.org/10.1590/S0006-87052008000200002

Ribeiro, N. D. (2010). Potencial de aumento da qualidade nutricional do feijão por melhoramento genético. Semina: Ciências Agrárias, 31, 1367-1376.

Rosa, S. S., Ribeiro, N. D., Jost, E., Reiniger, L. R. S., Rosa, D. P., Cerutti, T. and Possobom, M. T. D. F. (2010). Potential for increasing the zinc content in common bean using genetic improvement. Euphytica, 175, 207-213. https://doi.org/10.1007/s10681-010-0163-6

Santos, P. R., Costa, K. D. S., Nascimento, M. R., Lima, T. V., Souza, Y. P., Costa, A. F. and Silva, J. W. (2018). Simultaneous selection for yield, stability, and adaptability of carioca and black beans. Pesquisa Agropecuária Brasileira, 53, 736-745. https://doi.org/10.1590/ s0100-204x2018000600010

Silva, F. B., Ramalho, M. A. P. and Abreu, Â. F. B. (2007). Seleção recorrente fenotípica para florescimento precoce de feijoeiro 'Carioca'. Pesquisa Agropecuária Brasileira, 42, 1437-1442. https://doi.org/10.1590/S0100-204X2007001000010

Silva, C. A., Abreu, Â. F. B., Ramalho, M. A. P. and Maia, L. G. S. (2012). Chemical composition as related to seed color of common bean. Crop Breeding and Applied Biotechnology, 12, 132-137. https://doi.org/10.1590/S1984-70332012000200006 
Wander, A. E. (2007). Produção e consumo de feijão no Brasil, 1975-2005. Informações Econômicas, 37, 7-21.

Welch, R. M. (2002). The impact of mineral nutrients in food crops on global human health. Plant and Soil, 247, 83-90. https://doi. org/10.1023/A:1021140122921

Wessells, K. P. and Brown, K. H. (2012). Estimating the Global Prevalence of Zinc Deficiency: Results Based on Zinc Availability in National Food Supplies and the Prevalence of Stunting. PLoS One, 7, e50568. https://doi.org/10.1371/journal.pone.0050568

Zemolin, A. E. M., Ribeiro, N. D., Casagrande, C. R., Silva, M. J. and Arns, F. D. (2016). Genetic parameters of iron and zinc concentrations in Andean common bean seeds. Acta Scientiarum. Agronomy, 38, 439-446. https://doi.org/10.4025/actasciagron.v38i4.30652 